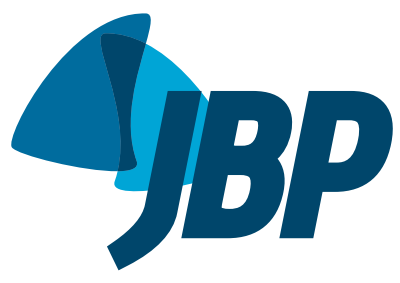

\title{
Clinical, functional, and cytological evaluation of sputum in postinfectious bronchiolitis obliterans: a possible overlap with asthma?
}

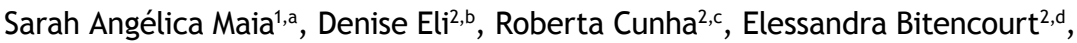 \\ Carlos Antônio Riedi1,e, Herberto José Chong Neto ${ }^{1, f}$, \\ Débora Carla Chong e Silva1,g, Nelson Augusto Rosário Filho, h
}

\section{DEAR EDITOR:}

Postinfectious bronchiolitis obliterans (PIBO) is a chronic obstructive pulmonary disease associated with inflammation of the lower airways. The inflammatory process is secondary to infectious bronchiolitis, which can be caused by viruses, atypical germs (especially Mycoplasma pneumoniae), and other bacteria. ${ }^{(1,2)}$ Although the clinical manifestations of PIBO can vary widely, its main characteristic is that patients with the condition present with signs and symptoms of a severe and persistent lower airway obstruction. ${ }^{(2)}$

The objective of the present study was to evaluate the clinical presentation, pulmonary function, CT findings, and sputum cellularity in patients with PIBO, as well as to correlate sputum cell pattern with spirometry and other imaging findings, clinical manifestations, and atopy.

This is a cross-sectional analytical study with patients diagnosed with PIBO and under follow-up at the Pediatric Pulmonology Center of the Clinical Hospital Complex of the Federal University of Paraná, Curitiba, state of Paraná, Brazil. The study included patients under 21 years of age with a diagnosis of PIBO related to a history of severe viral bronchiolitis before the onset of the respiratory symptoms and imaging studies with radiological findings showing involvement of the small airways and/or spirometry characterizing an obstructive defect. Exclusion criteria were the presence of other lung diseases, such as cystic fibrosis, primary or secondary immunodeficiencies, and other chronic pulmonary diseases.

After selection, patients underwent an initial clinical evaluation followed by complete spirometry-satisfying the acceptability and repeatability criteria established by international guidelines ${ }^{(3)}$-and post-bronchodilator (salbutamol, $400 \mu \mathrm{g}$ ) evaluation. The classification of the obstructive ventilatory defect into mild or moderate followed the recommendations of the American Thoracic Society. ${ }^{(4)}$ The bronchodilator test was considered positive when the difference in $\mathrm{FEV}_{1}$ was greater than $12 \%$ of the predicted value, as recommended by the Global Initiative for Asthma. ${ }^{(5)}$ Sputum was induced via inhalation of a hypertonic saline solution, using a $2 \mathrm{~L} / \mathrm{min}$ oxygen cylinder, and with the assistance of a physical therapist. The process used a hypertonic saline solution with concentrations gradually increasing from $3 \%$ to $5 \%$ and $7 \%$, when necessary, and lasted a minimum of 20 min per patient. After the minimum time, patients were stimulated to cough and expectorate into a sterile vial. The processes of sputum induction and sample processing followed a laboratory technique described by Pizzichini et al. (6) Only samples with cell viability above $50 \%$ were considered for the analysis. ${ }^{(7)}$ The patterns found were divided into eosinophilic (eosinophils $>2.5 \%$ and neutrophils $\leq 54 \%$ ), neutrophilic (eosinophils $\leq$ $2.5 \%$, neutrophils $>54 \%$ ), and mixed (eosinophilic/ neutrophilic; eosinophils $>2.5 \%$ and neutrophils $>$ $54 \%) .{ }^{(8)}$ The study was approved by the research ethics committee of the institution (Protocol No. 2.062.062). All parents/guardians gave written informed consent.

Our sample was initially composed of 23 patients with a clinical and radiological diagnosis of PIBO, who also met all other inclusion criteria. Of these, 1 patient refused to participate, and we were unable to get hold of another 9 patients. Therefore, 13 patients were enrolled in the study ( 8 of them male), with a median age of 12.1 years (range: 7-20 years). All 13 patients $(100 \%)$ had been hospitalized in their first year of life due to a disease whose manifestations were compatible with acute viral bronchiolitis. In addition, 8 (61.5\%) had a positive skin prick test for at least one aeroallergen, $7(53.8 \%)$ had rhinitis and/or atopic dermatitis, and 9 (69.2\%) were making use of inhaled corticosteroids.

All study participants had undergone at least one chest CT scan. The most prevalent CT finding was a mosaic pattern, found in 11 patients ( $84 \%)$; followed by bronchial wall thickening, in 10 (76\%); bronchiectasis, in $4(30 \%)$; and atelectasis, in $4(30 \%)$.

Of the 12 participants who underwent complete spirometry, $11(91.6 \%)$ had obstructive ventilatory defect. Of these, $7(63.6 \%)$ were classified as mild $\left(60 \%<\mathrm{FEV}_{1}<90 \%\right)$ and $4(36.4 \%)$ as moderate $\left(40 \%<\mathrm{FEV}_{1}<60 \%\right)$. Four patients had a positive bronchodilator test (33.3\%).

As for sputum cytology, the samples of 3 patients were considered inadequate for cytology studies for not having sufficient cell viability. Of the 10 samples

1. Universidade Federal do Paraná, Curitiba (PR) Brasil.

2. Complexo do Hospital de Clínicas, Universidade Federal do Paraná, Curitiba (PR) Brasil.

a. (iD) http://orcid.org/0000-0002-2908-4653; b. (iD http://orcid.org/0000-0003-3470-2599; c. (iD) http://orcid.org/0000-0001-7406-5286;

d. (iD http://orcid.org/0000-0002-7501-0647; e. (iD) http://orcid.org/0000-0002-6044-3327; f. (iD) http://orcid.org/0000-0002-7960-3925;

g. (iD http://orcid.org/0000-0002-7385-4598; h. (iD http://orcid.org/0000-0002-8550-8051 
Table 1. Clinical, functional, and CT variables in relation to sputum cell pattern $(N=10)$.

\begin{tabular}{lccc} 
Variables & $\begin{array}{c}\text { Cell pattern } \\
\text { Neutrophilic } \\
(\mathbf{n}=\mathbf{4})\end{array}$ & $\begin{array}{c}\text { Eosinophilic/neutrophilic } \\
(\mathbf{n}=\mathbf{4})\end{array}$ & $\begin{array}{c}\text { Eosinophilic } \\
\text { (n }=2)\end{array}$ \\
Positive skin prick test & 3 & 3 & 2 \\
Daily symptoms & 2 & 1 & 1 \\
Symptoms when exercising & 1 & 2 & 2 \\
Bronchiectasis & 0 & 2 & 0 \\
Ground-glass opacities & 1 & 2 & 0 \\
Positive bronchodilator test & 1 & 2 & 1 \\
\hline
\end{tabular}

considered viable, 4 (40\%) had a neutrophilic pattern; $4(40 \%)$ had a neutrophilic/eosinophilic pattern (mixed); and 2 (20\%) had an eosinophilic pattern. One of the samples was considered neutrophilic in spite of having a neutrophil rate below $54 \%$ because of its high cell viability and absence of eosinophils.

Sputum cytological patterns were compared with the CT findings, skin prick test results, presence or absence of daily symptoms and/or symptoms when exercising (especially dry cough and dyspnea), and bronchodilator test results (Table 1 ).

PIBO is a rare chronic lung disease resulting from severe lung injury following acute infectious bronchiolitis that causes varying degrees of inflammation with narrowing or total obliteration of the small airways in susceptible individuals. ${ }^{(9)}$

Supposedly, sputum cytology findings should be similar to those of previous bronchoalveolar lavages, ${ }^{(10)}$ with a marked increase in the number of neutrophils. However, only 4 patients presented an exclusively neutrophilic pattern, and, in 2, the pattern was predominantly eosinophilic, contrary to the initial assumption. Such disagreement was seen in atopic patients with a positive skin prick test and a diagnosis of concomitant rhinitis, indicating a probable coexistence of allergic asthma with previously diagnosed PIBO, an overlap suggested in a previous study. ${ }^{(11)}$
The bronchodilator test turned out positive in all cytological patterns, including the exclusively neutrophilic one, corroborating studies with long-term follow-up of patients with PIBO. ${ }^{(12,13)}$ Those studies have shown severe and permanent impairment of lung function, though air trapping slowly decreased with patient growth. ${ }^{(1,12,13)}$

There were no significant correlations between sputum cellularity and the clinical, functional, and CT variables studied. The lack of statistical correlation between the variables in the present study was probably due to the small sample size; the low prevalence of the disease represents an analytical challenge.

The lack of predominance of a specific cytological pattern could suggest a potential overlap of PIBO and asthma, which can indicate a need for new diagnostic and therapeutic approaches aimed at controlling both diseases. A deeper understanding of PIBO will favor an individualized approach of these cases. Similar multicenter studies may help deepen our understanding by providing us with the possibility of evaluating larger samples of such a rare disease.

\section{ACKNOWLEDGMENTS}

We would like to give special thanks to our medical student, Thaísa Vieira Sonnberg, for proofreading and conforming the text to the journal's standards.

\section{REFERENCES}

1. Mattiello R, Vidal PC, Sarria EE, Pitrez PM, Stein RT, Mocelin HT, et al. Evaluating bronchodilator response in pediatric patients with post-infectious bronchiolitis obliterans: use of different criteria for identifying airway reversibility. J Bras Pneumol. 2016;42(3):174-8. https://doi.org/10.1590/S1806-37562015000000065

2. Castro-Rodriguez JA, Giubergia V, Fischer GB, Castaños C, Sarria EE Gonzalez R, et al. Postinfectious bronchiolitis obliterans in children: the South American contribution. Acta Paediatr. 2014;103(9):913-21. https://doi.org/10.1111/apa.12689

3. Miller MR, Hankinson J, Brusasco V, Burgos F, Casaburi R, Coates A et al. Standardisation of spirometry. Eur Respir J. 2005;26(2):319-38. https://doi.org/10.1183/09031936.05.00034805

4. Lung function testing: selection of reference values and interpretative strategies. American Thoracic Society. Am Rev Respir Dis. 1991;144(5):1202-18. https://doi.org/10.1164/ajrccm/144.5.1202

5. Global Initiative for Asthma [homepage on the Internet]. Bethesda: Global Initiative for Asthma [cited 2019 Feb 01]. Global Strategy for Asthma Management and Prevention 2018. Available from: www. ginasthma.org

6. Pizzichini E, Pizzichini MM, Efthimiadis A, Evans S, Morris MM,
Squillace D, et al. Indices of airway inflammation in induced sputum: reproducibility and validity of cell and fluid-phase measurements. Am J Respir Crit Care Med. 1996;154(2 Pt 1):308-17. https://doi. org/10.1164/ajrccm.154.2.8756799

7. Spanevello A, Confalonieri M, Sulotto F, Romano F, Balzano G, Migliori GB, et al. Induced sputum cellularity: Reference values and distribution in normal volunteers. Am J Respir Crit Care Med. 2000;162(3 Pt 1):1172-4. https://doi.org/10.1164/ ajrccm.162.3.9908057

8. Lex C, Payne DN, Zacharasiewicz A, Li AM, Wilson NM, Hanse $T$, et al. Sputum induction in children with difficult asthma: safety, feasibility, and inflammatory cell pattern. Pediatr Pulmonol. 2005;39(4):318-24. https://doi.org/10.1002/ppul.20159

9. Mauad T, Dolhnikoff M; São Paulo Bronchiolitis Obliterans Study Group. Histology of childhood bronchiolitis obliterans. Pediatr Pulmonol. 2002; 33(6):466-74. https://doi.org/10.1002/ppul.10097

10. Koh YY, Jung DE, Koh JY, Kim JY, Yoo Y, Kim CK. Bronchoalveolar cellularity and interleukin-8 levels in measles bronchiolitis obliterans. Chest. 2007;131(5):1454-60. https://doi.org/10.1378/chest.06-0188

11. Bandeira T, Negreiro F, Ferreira R, Salgueiro M, Lobo L, Aguiar P, 
et al. Clinical, radiological, and physiological differences between obliterative bronchiolitis and problematic severe asthma in adolescents and young adults: the early origins of the overlap syndrome? Pediatr Pulmonol. 2011;46(6):573-80. https://doi. org/10.1002/ppul.21405

12. Colom AJ, Maffey A, Garcia Bournissen F, TeperA. Pulmonary function of a paediatric cohort of patients with postinfectious bronchiolitis obliterans. A long term follow-up. Thorax. 2015;70(2):169-74. https:// doi.org/10.1136/thoraxjnl-2014-205328

13. Rosewich M, Eckrich J, Zielen S. Long-term lung function in postinfectious bronchiolitis obliterans. Thorax. 2015;70(8):792. https://doi.org/10.1136/thoraxjnl-2015-206998 